Електронне наукове фахове видання «Адаптивне управління: теорія і практика.

ПОЧУСВА ОЛЬГА

https://orcid.org/0000-0001-6954-5197

кандидат педагогічних наук, доцент кафедри педагогіки, іноземної філології та перекладу

Харківського національного

економічного університету

імені Семена Кузнеця

\title{
МЕХАНІЗМИ ОРГАНІЗАЦІЇ ПЕДАГОГІЧНОЇ ВЗАЕМОДІЇ ЗІ СТУДЕНТАМИ ЗАКЛАДІВ ВИЩОЇ ОСВІТИ
}

Анотація. Сьогодні сучасне суспільство висуває все більш високі вимоги до освіти, яка знаходиться в постійному оновленні під впливом вимог роботодавців, розвитку науки й техніки, потреб та інтересів суспільства і в самому здобувачі в процесі навчання. Нині в освіті робиться наголос на створенні нового універсального знання, яке відповідає критеріям об'єктивності, фундаментальності та відповідає вимогам мислення нового часу. Ключовою умовою побудови освіти нового типу є взаємодія між знаннями, досвідом і розумінням. Розглядаючи особистісну взаємодію викладача та здобувачів у процесі засвоєння інформації, можна зазначити, що викладачу необхідно вибудовувати освітню діяльність 3 урахуванням фізичних і ментальних та інтелектуальних можливостей здобувачів. Усе частіше висловлюється думка про те, що в педагогічній взаємодії відбувається не тільки обмін інформацією, але й цінностями, способами життєдіяльності, нормами, етичними установками; їх відбір і засвоєння носить виборчий характер i залежить від соціально-психологічного клімату організації, у якій відбувається взаємодія. Актуальним є сценарний підхід до побудови взаємодії, який дає можливість подолати механічність, стереотипність взаємодії, дозволяє врахувати індивідуальні особливості здобувача й викладача, дозволяє викладачеві здійснювати непрямі педагогічні впливи. Для визначення якісних показників педагогічної взаємодії між викладачем і студентами спочатку слід визначити ефективні методи педагогічної взаємодії та рівні. Педагогічна взаємодія нами буде розглядається як цілеспрямований педагогічний процес взаємного обміну між викладачем і здобувачем у процесі їх спільної діяльності, обміном досвідом, емоціями при системному здійсненні комунікативних дій викладача, метою яких $\epsilon$ викликання відповідної реакції з боку здобувача.

Ключові слова: педагогічна взаємодія, здобувачі, викладачі, освітніх процес, методи педагогічної взаємодії, рівні педагогічної взаємодії. 
Електронне наукове фахове видання «Адаптивне управління: теорія і практика.

Серія «Педагогіка»

Випуск 11 (21), 2021

Вступ Сучасні активні перетворення в суспільстві, гуманізація й демократизація сприяють оновленню системи вищої освіти. Головною метою таких перетворень $є$ розкриття індивідуальних здібностей, створення сприятливих умов для розвитку творчої та професійної активності майбутніх фахівців. Якість та ефективність освітнього процесу, успішність навчання в закладах вищої освіти багато в чому визначається характером міжособистісної взаємодії між викладачем $\mathrm{i}$ здобувачем. Одним з найбільш важливих елементів $є$ побудова моделі педагогічної взаємодії в системі "викладач-здобувач", що являє собою систему взаємних впливів суб'єктів, включених в спільну діяльність на основі загальних цілей освіти. Подібна взаємодія має велике принципове значення з точки зору аксіологічної складової, оскільки ця взаємодія впливає на формування системи цінностей майбутнього фахівця.

Ефективність педагогічної взаємодії на заняттях залежить від безлічі факторів (успішного визначення цілей спільної діяльності, відповідності педагогічної тактики конкретному завданню даної взаємодії, активності здобувачів). Серед них важливу роль відіграє фактор оптимального вибору методів навчання, реалізація яких в конкретних умовах освітнього процесу. УДК дає високий рівень якості підготовки здобувачів. Актуальним $\epsilon$ використання методів активного навчання, а саме: проблемних лекцій, групових дискусій, аналізу конкретних ситуацій, рольових та ділових ігор, кейсів, які поряд 3 традиційними поясненням, розповіддю, бесідою сприяли б підвищенню ефективності, якості та результативності освітнього процесу узакладі вищої освіти.

Аналіз останніх досліджень і публікацій. Питанням взаємодії викладача і здобувача в процесіпрофесійної підготовки присвячено багато досліджень: Б. Ананьев, Г. Андрєєва, Т. Кожушкіна, В. Куніцина, М. Обозов, О. Яструб, C. Ситнік (міжособистісна взаємодія), М. Новікова, П. Юркевича, П. Каптерева (сократичний, евристичний способи навчання), Г. Афанасьєва, С. Горбачев, С. Гринько (соціальні аспектизаємодіï), Т. Василишина, Л. Карамушка, Т. Коломієць， Л. Подоляк， В. Юрченко (психологія міжособистісної взаємодії), В. Беспалько, А. Бодалев, П. Пидкасистый, Г. Селевко (місце та роль педагогічної взаємодіï у цілісному педагогічному процесі), В.Кан-Калік і

() Українська інженерно-педагогічна академія

(c) ГО «Школа адаптивного управління соціально-педагогічними системами»

(C) Почуєва О. 
Електронне наукове фахове видання «Адаптивне управління: теорія і практика.

Серія «Педагогіка»

Випуск 11 (21), 2021

Н. Нікандров(соціально-психологічний аспект), К. Ібрагімова, Л. Кизименко, Л. Бєдна (психологічний аспект взаємодія). О. Гончар, Н. Бібік, М. Подберезьський (якість зворотногозв'язку взаємодії), М. Свтух (педагогічна діяльність на основі взаємодії). Але не зважаючи на велику кількість досліджень, важливо відзначити, що на нині трактування терміну «педагогічна взаємодія» $є$ досить суперечливим.

Метою статті $\epsilon$ визначення ключових методів та рівнів педагогічної взаємодії викладачів і майбутніх менеджерів організацій у процесі професійної підготовки.

Викладення основного матеріалу. У сучасних умовах освіта частіше розглядається як процес взаємодії та взаємопроникнення учасників освітнього процесу. Ми згодні з думкою більшості науковців, що взаємодія в системі «викладач-здобувач» $є$ найбільш прогресивною та ефективною. Оскільки в цьому процесі спостерігається постійний зворотний зв'язок, який коригує діяльність здобувачів з боку викладача. У ході реалізації педагогічної взаємодії викладачеві слід орієнтуватися на здобувача, актуалізувати його до пізнання себе, до осмислення сильних і слабких сторін своєї особистості, створювати умови для саморозвитку.

Для виокремлення методів та рівнів як ключових елементів педагогічної взаємодії між викладачем та здобувачам у процесі професійної підготовки розглянемо теоретичні аспекти «взаємодії» та «педагогічної взаємодії». Філософський словник тлумачить термін «взаємодія» як процес впливу тіл одне на одного. Взаємодія визначає існування та структурну організацію будь-якої матеріальної системи, іï об'єднання поряд із іншими тілами в систему вищого порядку [11].

У загальному значенні поняття «взаємодія» відображає універсальний вплив об'єктів один на одного. Через взаємодію людина осягає природні та суспільні явища й процеси, орієнтується в навколишній реальності, визначає способи свого мислення й поведінки. 3 цим поняттям пов'язана й потреба людини в спілкуванні, навчанні, освіті, власному розвитку. 
Електронне наукове фахове видання «Адаптивне управління: теорія і практика.

Серія «Педагогіка»

Випуск 11 (21), 2021

На думку В. Пітюкова, взаємодія викладача й здобувача - це взаємний вплив один на одного, особливі рівноправні відносини, які дають можливість реалізуватися повною мірою будь-якої позиції кожного суб'єкта педагогічної взаємодії [9].

Під педагогічною взаємодією В. Ляудіс розуміє систематичне, постійне здійснення комунікативних дій педагога, викладача, учителя 3 метою викликання відповідної реакції з боку учня [7].

Ю. Блошкіна вважає, що педагогічна взаємодія буде в тому випадку, якщо в ній педагоги сприяютимуть становленню або зміні позицій, здібностей, навичок і знань у вихованців [2].

Ю. Бабанський пов'язує визначення досліджуваного процесу 3 характеристикою позицій, займаних його безпосередніми суб'єктами, і вважає, що взаємна активність, співпраця педагогів і вихованців у процесі їх спілкування відбивається терміном «педагогічна взаємодія» [1].

А. Леонтьєв визначає, що педагогічна взаємодія - це «професійне спілкування викладача зі здобувачами під час навчання чи поза ним, що має певні педагогічні функції, і спрямоване на створення сприятливого психологічного клімату, а також на іншого роду психологічну оптимізацію освітньої діяльності й відносини між викладачами та здобувачами» [6].

I. Зязюн, розглядаючи педагогічну взаємодію, зазначає, що це основа продуктивного спілкування, яка виховує громадянина своєї країни й творця власного життя, гармонійну та всебічно розвинену особистість [5].

В. Пітюков констатує, що в процесі взаємодії сторони не тільки висловлюють судження та обмінюються інформацією, а й діляться своїми оцінками 3 приводу висунутих ними тез, оцінюють, висловлюють і демонструють взаємні симпатії й антипатії. У цей момент обов'язково відбувається розкриття та трансляція індивідуального "Я" кожного з учасників спілкування [8].

О. Гочар, визначає педагогічну взаємодію як складне явище, що передбачає цілеспрямований взаємообмін й взаємозбагачення сеансами навчальної діяльності, 
Електронне наукове фахове видання «Адаптивне управління: теорія і практика.

Серія «Педагогіка»

Випуск 11 (21), 2021

досвідом, емоціями та настановами, що відбувається у вигляді діяльності або комунікації, що опосередковані міжособистісними відносинами [3].

Таким чином, можна констатувати, що взаємодія є одним 3 основних способів активізації саморозвитку здобувача. У цьому процесі викладач допомагає здобувачам усвідомити себе як особистість, виявити й розкрити свої можливості, розвинути особистісно значущі якості. У той же час, на нашу думку, якісна педагогічна взаємодія не можлива без ефективної спільної діяльності.

Актуальними, на нашу думку, є виокремлені Б. Грудиніним основні ознаки спільної діяльності, а саме: наявність спільних цілей для учасників взаємодії; погоджене, координоване виконання розподілених та об’єднаних індивідуальних діяльностей усіх учасників; необхідність в управлінні; потреба, що внутрішньо притаманна спільній діяльності; наявність єдиного завершального результату, спільного для учасників діяльності; єдине просторово-часове функціонування учасників взаємодії [4].

М. Подберезьський у своїх дослідженнях визначає, що педагогічна взаємодія характеризується як загальними властивостями взаємодії в цілому, так і специфічними, які відповідають сфері реалізації [10].

До властивостей загального порядку М. Подберезьський відносить:

1) причинну зумовленість, адже немає жодного явища в педагогічному просторі, в основі якого не відбувалася б взаємодія;

2) суперечливість педагогічних взаємодій, яка полягає в зіткненні, 3 одного боку, потреби об’єктів і суб'єктів зберегти себе в незмінному вигляді, а $з$ іншого - у прагненні зміцнити свій стан за рахунок розширення меж свого впливу; в одночасній відкритості й ізольованості педагогічних систем; у різнохарактерному зв’язку суб'єктів і об’єктів, залучених до педагогічної взаємодії; у незбігові теоретичних побудов 3 реаліями практичного здійснення тощо;

3) активність, яка забезпечує поступальний розвиток системи, i реактивність, яка регулює ефективність педагогічних взаємодій; 
Електронне наукове фахове видання «Адаптивне управління: теорія і практика.

4) виникнення нової якості у зв’язках і станах суб’єктів і об’єктів як результат педагогічної взаємодії [10].

До специфічних властивостей педагогічних взаємодій

М. Подберезьський відносить наступні:

- детермінованість соціокультурною й освітньою ситуаціями; взаємозв’язок соціальних, психологічних і власне педагогічних підходів в організації педагогічних взаємодій;

- послідовність, безперервність й одночасну дискретність педагогічних взаємодій;

- спрямованість на передавання знань, умінь суспільного досвіду підростаючому поколінню для соціального відтворення суспільства;

- необхідність створення умов для самоактуалізації й самореалізації кожного суб'єкта, залученого до системи педагогічних взаємодій;

- діалектичний взаємозв'язок 3 процесом спілкування та його функціями як основою педагогічного процесу;

- закономірну асиметричність позицій суб’єктів педагогічної взаємодії, яка створює підстави для розвитку й саморозвитку суб'єктів і об’єктів у педагогічному просторі [10].

Проаналізувавши ключові теоретичні питання педагогічної взаємодії, надамо характеристику методів педагогічної взаємодії, які викладач може використовувати під час реалізації освітнього процесу.

У педагогічній практиці під методом розуміють впорядкований спосіб діяльності по досягненню освітніх цілей. До методів педагогічної взаємодії можна віднести такі: активний, комунікативний, проблемний, метод ділової гри, метод проєктів, метод переконання та самостійну роботу здобувачів. Охарактеризуємо деякі методи педагогічної взаємодії.

Комунікативний метод педагогічної взаємодії займає чільне місце в процесі навчання, оскільки слово викладача $є$ ключовим в донесенні інформації. Викладач повинен бути переконливим у дискусіях, при 
Електронне наукове фахове видання «Адаптивне управління: теорія і практика.

Серія «Педагогіка»

Випуск 11 (21), 2021

постановці проблемних питань рідко розповідає сам, а частіше веде жваву бесіду зі здобувачами, заохочуючи їх до висловлювань своєї думки.

Ділова гра - метод, що являє собою рольову гру з різними, часто протилежними інтересами іï учасників і необхідністю прийняття будь-якого рішення після іiі закінчення. Ділові ігри допомагають формувати в здобувачів комунікативні здібності, толерантність, уміння працювати в малих групах, самостійність мислення.

Метод дискусій дозволяє викладачу розглянути наукову, соціальну, моральну проблеми 3 різних точок зору. При цьому здобувачі уважно слухають, поважають думки інших, висловлюють ті позиції, що не збігаються із загальною точкою зору, логічно й чітко трактують свою думку, тобто розвивають в процесі навчання навички критичного мислення .

Використання проблемний методу змінює роль підручників в освітньому процесі. Замість епічного викладу фактів навчальний матеріал групується навколо актуальних наукових i соціальних проблем, викладаються різні теоретичні підходи до їх вирішення, формуються проблемні завдання й питання для здобувачів.

Метод проєктів використовується, коли виконання завдання вимагає тривалого часу й пов'язане зі збором оригінального матеріалу, проведення опитувань, спостережень. Цей метод не тільки реально робить здобувача суб'єктом навчання, а й учить виробляти важливі для сучасної інформаційної доби навички збору та обробки інформації, що надходить з різних джерел.

Самостійна робота є дуже важливою, оскільки формує в здобувачів навички самоосвіти, формує вміння планувати та організовувати свою роботу, розвиває певні риси самоконтролю, сприяє удосконаленню умінь обробляти й аналізувати інформацію, робити узагальнення, вносити необхідні корективи в роботу.

Засобами педагогічної взаємодії здобувачів можуть бути навчальні програми, навчальні та навчально-методичні посібники, проблемні, 
Електронне наукове фахове видання «Адаптивне управління: теорія і практика.

Серія «Педагогіка»

Випуск 11 (21), 2021

прикладні, контрольні завдання, навчальні комплексні програми та їх елементи, опорні конспекти, медіапрограми, дидактичні матеріали.

До організаційних форм педагогічної взаємодії відносяться індивідуальні, групові, парні та фронтальні форми. Реалізація якісного освітнього процесу неможлива без оптимального поєднання на окремих етапах заняття визначених форм роботи. У якості результату нами визначені наступні рівні сформованості педагогічної взаємодії викладача та студентів.

Також не можливо оцінити якість педагогічної взаємодії, не визначивши ii якісних показників. Проаналізувавши наукові дослідження, нами були виокремленні три рівні педагогічної взаємодії.

Низькопродуктивний рівень характеризується переважанням діяльнісного компонента по відношенню до орієнтації на спілкування й на саму особистість здобувача в рамках освітнього процесу. Ініціатором такої взаємодії виступає викладач; спрямованість впливу однобіччя від викладача до здобувача; здатності здобувачів до творчості реалізуються слабо; в освітній діяльності студентів проявляється фрагментарний інтерес, елементи запам'ятовування, відтворення, старанності; взаємодія відбувається на репродуктивному рівні. На цьому рівні з боку здобувачів спостерігається пасивна позиція по відношенню до професійного становлення, позиція пристосування, у якій головним є отримання оцінок.

Середньопродуктивний рівень визначається, якщо поряд 3 діяльністю реалізується спрямованість впливу викладача на спілкування зі здобувачем, у результаті чого виникають вольові потенціали, духовні та емоційні зв'язки. Сфера особистих інтересів викладача й здобувача розширюється, спілкування набуває суб'єктного характеру з обох боків, відбувається зміна в бік ситуативного впливу здобувача на викладача. У здобувача з'являється активність й елементи творчості в спільній з викладачем діяльності.

Високопродуктивний рівень передбачає спрямованість впливу викладача на особистість здобувача i на свою власну особистість. Пріоритетними стають кінцеві цілі та цінності; духовні зв'язки суб'єктів

(c) Українська інженерно-педагогічна академія

(ㄷ ГО «Школа адаптивного управління соціально-педагогічними системами»

() Почуєва О. 
Електронне наукове фахове видання «Адаптивне управління: теорія і практика.

Серія «Педагогіка»

Випуск 11 (21), 2021

визначають їх діяльнісні відносини; позиції учасників стають справді суб'єктними завдяки співпраці, розподілу активності, творчості та ініціативі в спільній діяльності. 3 боку здобувача здійснюється самопроєктування свого професійного становлення; спостерігається раціоналізація, самостійність, співпраця з викладачем. 3 боку викладача відбувається сприйняття здобувача як рівноправного партнера, активного суб'єкта в освітньому процесі; будується продумана організація самостійної роботи здобувачів; ведеться спільний пошук істини; здобувачам надається право вибору.

На основі аналізу методів, прийомів, форм організації педагогічної взаємодії між викладачами та здобувачами Харківського національного економічного університету імені Семена Кузнеця першого року навчання магістерських програм «Бізнес-адміністрування» (5 здобувачів), «Бізнесстатистика і аналітика» (бздобувачів), «Логістика» (5 здобувачів) було проведено дослідження, у межах якого були обрані респонденти - здобувачі однієї спеціальності 073 менеджмент.

Здобувачам було запропоновано виокремити по 3 методи із запропонованих, які на їх думку більше сприяють якісній педагогічній взаємодії між здобувачами та викладачами (рис. 1.)

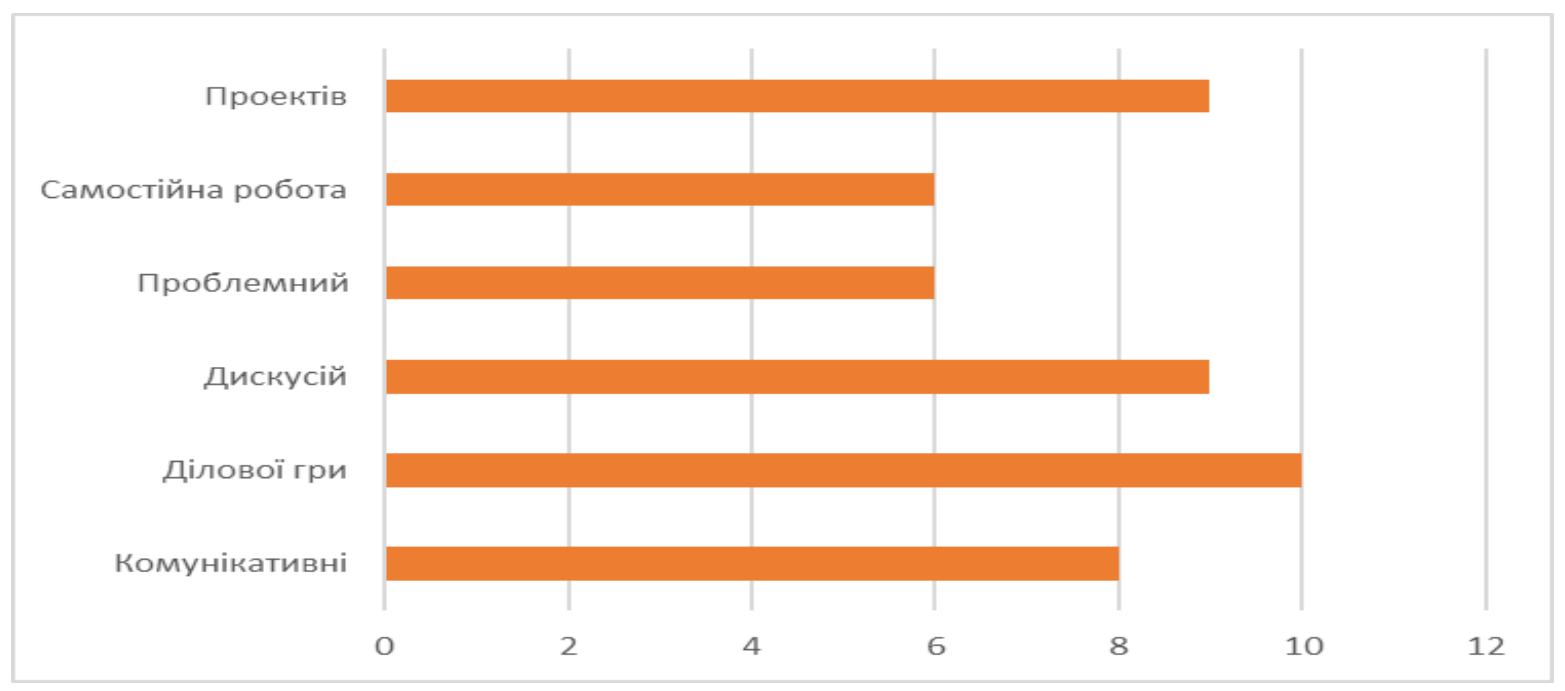

Рис 1. Методи, які сприяють якості й педагогічній взаємодії між здобувачем та викладачем (думка студентів)

Результати діагностування були наступними: найбільш ефективним, на думку, здобувачів є методи ділової гри, проектні методи та дискусії, оскільки,

( ) Українська інженерно-педагогічна академія

( Г ГО «Школа адаптивного управління соціально-педагогічними системами»

(ㄱ) Почуєва О. 
Електронне наукове фахове видання «Адаптивне управління: теорія і практика.

Серія «Педагогіка»

Випуск 11 (21), 2021

застосовуючи саме їx, відбувається активна співпраця між викладачем та здобувачем, так і між здобувачами. Відповідаючи на відкриті запитання, студенти зауважили, що саме під час застосованих методів педагогічної взаємодії вони можуть вільно спілкуватися між собою, працювати в команді при цьому викладач наближається в спілкуванні до здобувачів.

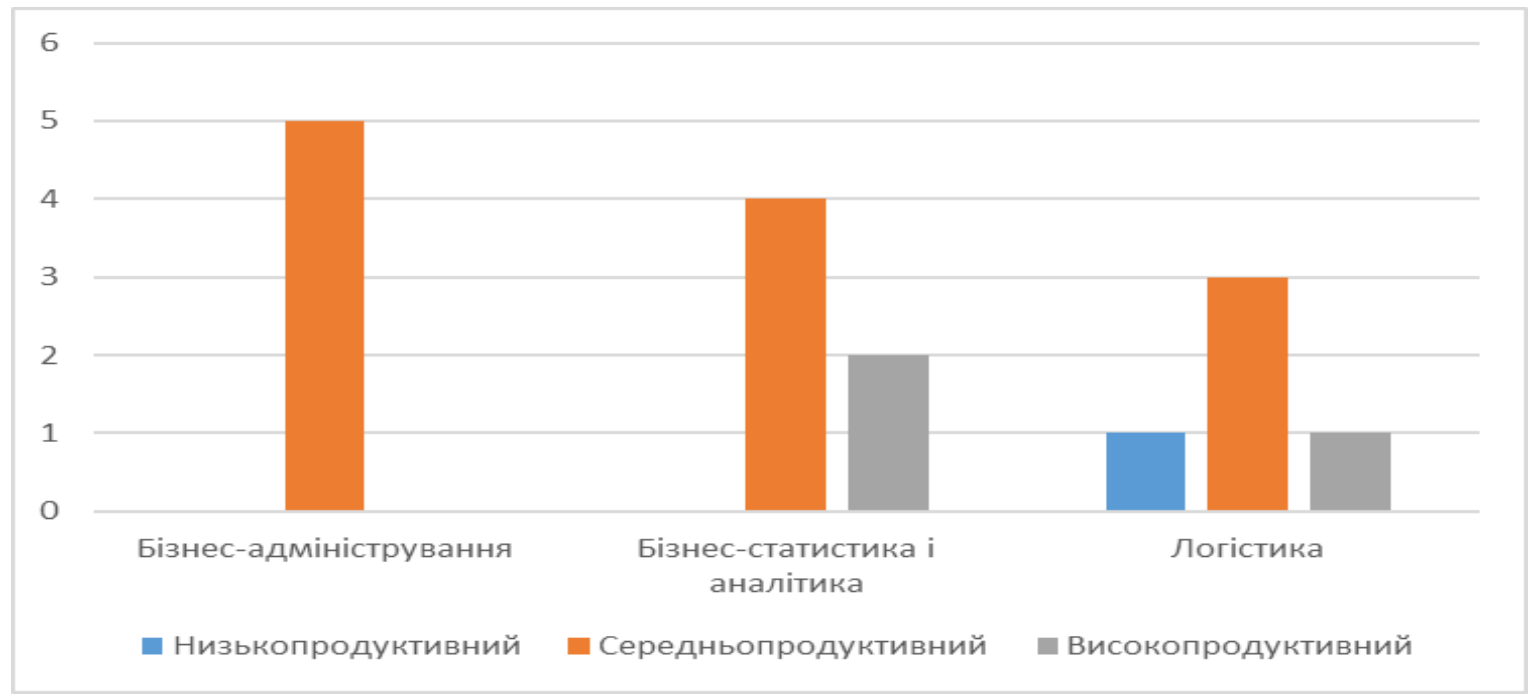

Рис. 2. Визначення рівня педагогічної взаємодії, загальний рівень взаємодії між здобувачами та викладачами (думка студентів)

Наступним етапом було запропоновано оцінити за допомогою визначених рівнів педагогічної взаємодії загальний рівень взаємодії між здобувачами та викладачами (рис 2.)

Отримані данні засвідчили, що їхня взаємодія з викладачами в більшості є в межах середньопродуктивного та високопродуктивного рівнів. Відповідаючи на відкриті питання, здобувачі висловлювали побажання мати більшу співпрацю 3 викладачем в якості як рівноправного партнера, активного суб'єкта в освітньому процесі.

У цілому вивчення стану проблеми педагогічної взаємодії викладача й здобувачів під час навчання дозволяє констатувати, що, хоча на цей день у наукових дослідженнях зроблено чимало щодо розкриття проблеми педагогічної взаємодії, у той же час зазначена проблема залишається актуальною й широке коло наукових питань в цій області залишається відкритим. 
Електронне наукове фахове видання «Адаптивне управління: теорія і практика.

На основі аналізу досліджуваної проблеми в теорії й практиці педагогічної освіти були виокремлені методи та рівні педагогічної взаємодії викладача та здобувача. Пріоритетне значення набуває особистісно-орієнтоване навчання, де особистості викладача й студентів є суб'єктами педагогічної взаємодії.

Висновки. Успішне здійснення педагогічної взаємодії між викладачем i здобувачем можливе лише в тому випадку, якщо між ними встановлюється двобічний зв'язок. При цьому взаємодія допомагає здійснювати регулюючі впливи. Завдяки цьому освітній процес починає здійснюватися з постійним урахуванням того, чого домігся кожен студент на кожному ступені навчання.

Подалышими перспективами с дослідження кореляції між обраними методами педагогічної взаємодії та якісною професійною підготовкою здобувачів. Цікавими напрямами досліджень є питання вивчення механізмів педагогічної взаємодії під час дистанційного навчання.

\section{СПИСОК ВИКОРИСТАНИХ ДЖЕРЕЛ}

1. Бабанский Ю.К. Избранные педагогические труды / Ю. Бабанський - Москва : Педагогика, 2000 . $-558 \mathrm{c}$.

2. Блошкина Ю.В. Формирование продуктивной деятельности студентов в процессе педагогического взаимодействия // Культура учебной деятельности студентов: Теория и практика формирования // Материалы Всероссийской научно-практической конференции. Барнаул: Изд-во БГПУ, 2003. 299 c. С.36-40.

3. Гончар О. Новітні технології суб'єкт-суб'єктної взаємодії учасників навчального процесу вищої школи URL: https://www.sportpedagogy.org.ua/html/journal/201203/PP201203.pdf\#page=41

4. Грудинін Б. Педагогічна взаємодія: вимоги в контексті особистісно орієнтованої освітньої 5_39_2014.pdf парадигмиURLhttps://library.sspu.edu.ua/wp-content/uploads/2018/04/Ped.nauki_---

5. Зязюн. И., Кривонос Н., Тарасевич Н. и др. Основы педагогического мастерства: учеб. пособие для пед. спец. высш. учеб. заведений/ И. Зазюн, Н. Кривонос, Н. Тарасевич - Москва: Просвещение, 2009. 302c.

6. Леонтьев А. Педагогическое общение / А. Леонтьев, Москва : Политиздат, 2007-304c.

7. Ляудис В. Я. Структура продуктивного учебного взаимодействия // Психологопедагогические проблемы взаимодействия учителя и учащихся. Москва : Педагогика, 1999. 38 с.

8. Питюков В.Ю. Основы педагогической технологии: учеб.-практ. пособие. / В. Питюков Москва : рос. пед. агенство, 2007. 174 с.

9. Питюков В. Ю. Основы педагогической технологии: Учебно-методическое пособие. 3-е изд., испр. и доп /В. Питюков Москва : Издательство «Гном и Д», 2001. 192с.

10.Подберезський $\mathrm{M}$. Характеристика особливостей педагогічної взаємодії URLhttps://pedpsy.duan.edu.ua/images/PDF/2011/2/7.pdf

11.Розенталь М. Философский словарь / [Адо А., Альтман В., Аникеев Н.]; под. ред. М. Розенталя. - 3-е изд. - Москва : Политиздат, 1975. - 496 с.

(C) Українська інженерно-педагогічна академія

(c) ГО «Школа адаптивного управління соціально-педагогічними системами»

(C) Почуєва О. 


\section{REFERENCES}

1. Babanskiy Yu.K. Izbrannye pedagogicheskie trudy / Yu. Babanskiy - Moskva : Pedagogika, $2000 .-558 \mathrm{~s}$.

2. Bloshkina Yu.V. Formirovanie produktivnoy deyatelnosti studentov v protsesse pedagogicheskogo vzaimodeystviya // Kultura uchebnoy deyatelnosti studentov: Teoriya i praktika formirovaniya // Materialy Vserossiyskoy nauchno-prakticheskoy konferentsii. Barnaul: Izd-vo BGPU, 2003. 299 s. S.36-40.

3. Honchar O. Novitni tekhnolohii subiekt-subiektnoi vzaiemodii uchasnykiv navchalnoho protsesu vyshchoi shkoly URL: https://www.sportpedagogy.org.ua/html/journal/201203/PP201203.pdf\#page $=41$

4. Hrudynin B. Pedahohichna vzaiemodiia: vymohy v konteksti osobystisno oriientovanoi osvitnoi paradyhmyURLhttps://library.sspu.edu.ua/wp-content/uploads/2018/04/Ped.nauki_---5_39_2014.pdf

5. Zyazyun. I., Krivonos N., Tarasevich H. i dr. Osnovy pedagogicheskogo masterstva: ucheb. posobie dlya ped. spets. vyssh. ucheb. zavedeniy/ I. Zazyun, N. Krivonos, N. Tarasevich - Moskva: Prosveshchenie, 2009. 302s.

6. Leontev A. Pedagogicheskoe obshchenie / A. Leontev, Moskva : Politizdat, 2007 - 304s.

7. Lyaudis V. Ya. Struktura produktivnogo uchebnogo vzaimodeystviya // Psikhologopedagogicheskie problemy vzaimodeystviya uchitelya i uchashchikhsya. Moskva : Pedagogika, 1999. 38 s.

8. Pityukov V.Yu. Osnovy pedagogicheskoy tekhnologii: ucheb.-prakt. posobie. / V. Pityukov Moskva : ros. ped. agenstvo, 2007. 174 s.

9. Pityukov V. Yu. Osnovy pedagogicheskoy tekhnologii: Uchebno-metodicheskoe posobie. 3-e izd., ispr. i dop /V. Pityukov Moskva : Izdatelstvo «Gnom i D», 2001. 192s.

10.Podberezskiy M. Kharakteristika osoblivostey pedagogichnoï vzacmodii URLhttps://pedpsy.duan.edu.ua/images/PDF/2011/2/7.pdf

11. Rozental M. Filosofskiy slovar / [Ado A., Altman V., Anikeev N.]; pod. red. M. Rozentalya. 3-e izd. - Moskva : Politizdat, 1975. - 496 s.

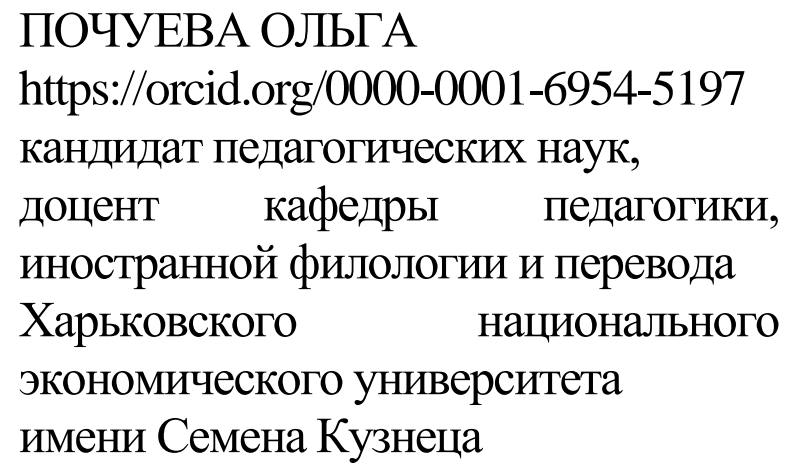

\section{МЕХАНИЗМЫ ОРГАНИЗАЦИИ ПЕДАГОГИЧЕСКОГО ВЗАИМОДЕЙСТВИЯ СО СТУДЕНТАМИ ВУЗОВ}

Аннотация. Сегодня современное общество предъявляет все более высокие требования к образованию, находящейся в постоянном обновлении под влиянием требований работодателей, развития науки и техники, потребностей и интересов общества и в самом студенте в процессе обучения. Сейчас в образовании делается упор на создании нового универсального знания, которое отвечает критериям объективности, фундаментальности и соответствует требованиям мышления нового времени. Ключевым условием построения образования нового типа

(с) Українська інженерно-педагогічна академія

(c) ГО «Школа адаптивного управління соціально-педагогічними системами»

(C) Почуєва О. 
Електронне наукове фахове видання «Адаптивне управління: теорія і практика.

является взаимодействие между знаниями, опытом и пониманием. Рассматривая личностную взаимодействие преподавателя и соискателей в процессе усвоения информации, можно отметить, что преподавателю необходимо выстраивать образовательную деятельность с учетом физических и ментальных и интеллектуальных возможностей соискателей. Все чаще высказывается мнение о том, что в педагогическом взаимодействии происходит не только обмен информацией, но и ценностями, способами жизнедеятельности, нормами, этическими установками; их отбор и усвоение носит избирательный характер и зависит от социально-психологического климата организации, в которой происходит взаимодействие. Актуальным является сценарный подход к построению взаимодействия, позволяющий преодолеть механичность, стереотипность взаимодействия, позволяет учесть индивидуальные особенности соискателя и преподавателя, позволяет преподавателю осуществлять косвенные педагогические воздействия. Для определения качественных показателей педагогического взаимодействия между преподавателем и студентами сначала следует определить методы педагогического взаимодействия и уровни. Педагогическое взаимодействие нами будет рассматривается как целенаправленный педагогический процесс взаимного обмена между преподавателем и соискателем в процессе их совместной деятельности, обмен опытом, эмоциями при системном осуществлении коммуникативных действий преподавателя, целью которых является вызывание соответствующей реакции со стороны студента.

POCHUIEVA OLHA https://orcid.org/0000-0001-6954-5197

$\mathrm{PhD}$, associate professor of pedagogy, foreign philology and translation Simon Kuznets Kharkiv National University of Economics

\section{MECHANISMS OF ORGANIZATION OF PEDAGOGICAL INTERACTION WITH HIGHER EDUCATION STUDENTS}

Abstract. Today, modern society places ever higher demands on education, which is constantly updated under the influence of the requirements of employers, the development of science and technology, the needs and interests of society and the student himself in the learning process. Now education emphasizes the creation of a new universal knowledge that meets the criteria of objectivity, fundamentality and meets the requirements of modern thinking. The key condition for building a new type of education is the interaction between knowledge, experience and understanding. Considering the personal interaction of the teacher and applicants in the process of assimilation of information, it can be noted that the teacher needs to build educational activities taking into account the physical and mental and intellectual capabilities of applicants. The opinion is expressed more and more often that in pedagogical

() Українська інженерно-педагогічна академія

(c) ГО «Школа адаптивного управління соціально-педагогічними системами»

(C) Почуєва О. 
interaction there is not only an exchange of information, but also values, ways of life, norms, ethical attitudes; their selection and assimilation is selective and depends on the socio-psychological climate of the organization in which the interaction takes place. The scenario approach to construction of interaction which allows to overcome mechanics, stereotypes of interaction, allows to consider individual features of the applicant and the teacher, allows the teacher to carry out indirect pedagogical influences is actual. To determine the qualitative indicators of pedagogical interaction between teacher and students, you must first determine the methods of pedagogical interaction and levels. Pedagogical interaction will be considered by us as a purposeful pedagogical process of mutual exchange between the teacher and the applicant in the process of their joint activities, exchange of experience, emotions in the systematic implementation of communicative actions of the teacher, which aim to provoke appropriate response from the student. 